\title{
PEMODELAN WAVELET NEURAL NETWORK UNTUK PREDIKSI NILAI TUKAR RUPIAH TERHADAP DOLAR AS
}

\author{
Tri Yani Elisabeth Nababan ${ }^{1}$, Budi Warsito ${ }^{2}$, Agus Rusgiyono ${ }^{3}$ \\ 1,2,3 Departemen Statistika, Fakultas Sains dan Matematika, Universitas Diponegoro \\ e-mail : budiwrst2@gmail.com
}

\begin{abstract}
Each country has its own currency that is used as a tool of exchange rate valid in the transaction process. In the process of transaction between countries often experience problems in terms of payment because of the difference in the value of money prevailing in each country. The price movement of the exchange rate or the value of foreign currencies that fluctuate fromtime to time it encouraged predictions of the value of the rupiah exchange rate against the U.S. dollar. Wavelet Neural Network (WNN) is a combination of methods between wavelet transforms and Neural networks. WNN modeling begins with wavelet decomposition resulting in wavelet coefficients and scale coefficients. Selection of in puts is based on PACF plots and divides into training data and testing data. To determine the final output by calculating the value of MAPEin data testing. The best architecture on WNN model for predict ion of the value of the rupiah exchange rate against the U.S. dollar is a model with sigmoid logistic activation function, 2 neurons in the input layer, 10 neurons in the hidden layer, and 1 neuron in the output layer. The MAPE value is obtained at $0.2221 \%$.
\end{abstract}

Keywords : maximal overlap discrete transform(MODWT), neural network wavelet, prediction, exchange rates

\section{PENDAHULUAN}

Pergerakan harga kurs atau nilai mata uang asing selalu berubah-ubah dari waktu ke waktu sesuai dengan hukum permintaan dan penawaran. Pergerakan kurs yang cenderung mengalami fluktuatif menyebabkan pihak-pihak yang berkepentingan kesulitan dalam mengambil keputusan. Transaksi valas di pasar valas tidak terlepas dari proses memprediksi atau menganalisa terlebih dahulu. Prediksi dilakukan untuk menentukan arah pergerakan mata uang tersebut. Prediksi kurs ini penting dilakukan untuk menghindari kerugian dan bahkan mendapat keuntungan dari pergerakan kurs.

Salah satu metode peramalan yang berkembang saat ini adalah menggunakan Neural Network. Neural network adalah paradigma pengolahan informasi yang terinspirasi oleh sistem saraf scara biologis, seperti proses informasi pada otak manusia. Feed fordward neural network (FFNN) salah satu jenis dari NN dimana neuron pada suatu layer hanya bisa berkoneksi dengan neuron yang berada pada layer yang berbeda. Beberapa tulisan yang berkaitan dengan pemodelan NN pada time series lebih banyak difokuskan pada pemodelan FFNN. Dengan berbagai keunggulan yang dimilikinya model ini mampu membuat prediksi dengan baik, lebih baik daripada model linier ARIMA.

Metode neural network memiliki beberapa keterbatasan yang menjadi kendala untuk mendapat hasil prediksi yang lebih baik. Praktisi matematika dan pasarmodal menggunakan metode wavelet transform untuk meningkatkan kemampuan neural network dalam melakukan prediksi data time series. Penerapan wavelet transform untuk membentuk masukan pada pelatihan neuralnetwork terbukti meningkatkan kemampuan jaringan dalam mengenali data yang belum pernah ditemui pada data pelatihan (Haikal, 2011). Transformasi wavelet terdapat dua macam yaitu Discrete Wavelet Transform (DWT) dan Continous Wavelet Transform (CWT). Pada DWT hanya diberlakukan aturan dimana DWT hanya dapat dilakukan pada ukuran sampel $2^{\mathrm{j}}$ untuk suatu bilangan bulat positif $\mathrm{j}$, sedangkan MODWT memiliki keunggulan yaitu dapat diberlakukan untuk setiap ukuran sampel $\mathrm{N}$ (Percival dan Walden, 2000). 
Prediksi data time series dapat digunakan sebagai bahan pertimbangan dalam pengambilan keputusan. Neural Network merupakan metode yang baik untuk memprediksi data time series, akan tetapi sulit dihindari karena adanya epoch (iterasi) yang banyak selama pelatihan. Sedangkan wavelet dapat dipakai untuk mendekomposisi dan merekontruksi data sehingga dapat mengurangi banyaknya epoch. Dari keunggulan model Wavelet dan Neural Network tersebut, kedua model akan digabungkan untuk mendapatkan hasil prediksi yang lebih akurat.

\section{TINJAUAN PUSTAKA}

\subsection{Wavelet}

Fungsi wavelet adalah suatu fungsi matematika yang mempunyai sifat-sifat tertentu diantaranya berosilasi di sekitar nol (seperti fungsi sinus dan cosinus) dan terlokalisasi dalam domain waktu, artinya pada saat nilai domain relatif besar, fungsi wavelet berharga nol (Warsito dkk, 2013). Fungsi wavelet dibedakan atas dua jenis, yaitu wavelet ayah $(\phi)$ dan wavelet ibu $(\psi)$. Fungsi wavelet mempunyai sifat;

$$
\int_{-\infty}^{\infty} \psi(t) d t=0 \operatorname{dan} \int_{-\infty}^{\infty} \phi(t) d t=1
$$

Dengan dilatasi diadik dan translasi integer, wavelet ayah dan wavelet ibu melahirkan keluarga wavelet yaitu:

$$
\begin{aligned}
\phi_{j, k}(t) & =2^{j / 2} \phi\left(2^{j} t-k\right) \\
\psi_{j, k}(t) & =2^{j / 2} \psi\left(2^{j} t-k\right)
\end{aligned}
$$

\subsubsection{Transformasi Wavelet Diskrit (DWT)}

Transformasi wavelet adalah sebuah fungsi konversi yang dapat digunakan untuk membagi suatu fungsi atau sinyal ke dalam komponen frekuensi yang berbeda, yang selanjutnya komponen-komponen tersebut dapat dipelajari sesuai dengan skalanya. Transformasi wavelet terdiri atas Transformasi Wavelet Kontinu atau Countinuous Wavelet Transform (CWT) dan Transformasi Wavelet Diskrit atau Discrete Wavelet Transform (DWT). CWT digunakan untuk sebuah fungsi yang berdomain bilangan real atas sumbu $x$ dan DWT digunakan untuk sebuah fungsi atas domain bilangan bulat.

Pada DWT hanya diberlakukan aturan dimana DWT hanya dapat dilakukan pada ukuran sampel $2^{\mathrm{j}}$ untuk suatu bilangan bulat positif $\mathrm{j}$. Terdapat dua filter pembangun DWT yaitu filter wavelet (h) dan filter skala (g). Menurut Pecival dan Walden (2000), suatu filter wavelet harus memenuhi persamaan (4).

$$
\sum_{l=0}^{L-1} h_{l}=0, \sum_{l=0}^{L-1} h_{l}^{2}=1 \text { dan } \sum_{l=0}^{L-1} h_{l} h_{l+2 m}=0
$$

dan filter skala harus memenuhi persamaan (5).

$$
\sum_{l=0}^{L-1} g_{l}=\sqrt{2} \text { atau } \sum_{l=0}^{L-1} g_{l}=-\sqrt{2}, \sum_{l=0}^{L-1} g_{l}^{2}=1 \text { dan } \sum_{l=0}^{L-1} g_{l} g_{l+2 n}=0
$$

untuk semua bilangan bulat $\mathrm{n}$ bukan nol.

Secara matematis DWT dapat dituliskan seperti pada persamaan (6).

$$
\boldsymbol{W}=\mathcal{W} \boldsymbol{X}
$$

dengan $\mathbf{W}=$ hasil DWT dan $\mathcal{W}=$ matriks transformasi berukuran nxn. 
Matriks transformasi $\mathcal{W}$ dibentuk dengan translasi dan dilatasi filter $\mathbf{h}$ dan $\mathbf{g}$ yang diberikan dengan tetap mempertahankan sifat-sifat filter pada setiap operasi translasi dan dilatasi. Misalkan untuk level pertama, diketahui $L=4$ dan $N>4$, maka matriks $W_{1}$ dan $V_{1}$ dapat dilihat sebagai berikut:

$$
W_{1}=\left[\begin{array}{ccccccccccccc}
h_{1} & h_{0} & 0 & 0 & 0 & \ldots & 0 & 0 & 0 & 0 & 0 & h_{3} & h_{2} \\
h_{3} & h_{2} & h_{1} & h_{0} & 0 & \ldots & 0 & 0 & 0 & 0 & 0 & 0 & 0 \\
\vdots & \vdots & \vdots & \vdots & \vdots & \ldots & \vdots & \vdots & \vdots & \vdots & \vdots & \vdots & \vdots \\
0 & 0 & 0 & 0 & 0 & \ldots & 0 & h_{3} & h_{2} & h_{1} & h_{0} & 0 & 0 \\
0 & 0 & 0 & 0 & 0 & \ldots & 0 & 0 & 0 & h_{3} & h_{2} & h_{1} & h_{0}
\end{array}\right]
$$

$\tilde{V}_{1}$ disusun berdasarkan dimana strukturnya sama dengan $\widetilde{W}_{1}$ namun $\tilde{h}_{l}$ diganti dengan $\tilde{g}_{l}$. Matriks filter skala dapat dilihat dengan struktur sebagai berikut:

$$
V_{1}=\left[\begin{array}{ccccccccccccc}
g_{1} & g_{0} & 0 & 0 & 0 & \ldots & 0 & 0 & 0 & 0 & 0 & g_{3} & g_{2} \\
g_{3} & g_{2} & g_{1} & g_{0} & 0 & \ldots & 0 & 0 & 0 & 0 & 0 & 0 & 0 \\
\vdots & \vdots & \vdots & \vdots & \vdots & \ldots & \vdots & \vdots & \vdots & \vdots & \vdots & \vdots & \vdots \\
0 & 0 & 0 & 0 & 0 & \ldots & 0 & g_{3} & g_{2} & g_{1} & g_{0} & 0 & 0 \\
0 & 0 & 0 & 0 & 0 & \ldots & 0 & 0 & 0 & g_{3} & g_{2} & g_{1} & g_{0}
\end{array}\right]
$$

Sehingga langkah pertama dari DWT dapat ditulis pada persamaan berikut ini,

$$
\mathcal{P}_{1} \boldsymbol{X}=\left[\begin{array}{l}
\mathcal{W}_{1} \\
\mathcal{V}_{1}
\end{array}\right] \boldsymbol{X}=\left[\begin{array}{l}
\mathcal{W}_{1} \boldsymbol{X} \\
\mathcal{V}_{1} \boldsymbol{X}
\end{array}\right]=\left[\begin{array}{l}
W_{1} \\
V_{1}
\end{array}\right]
$$

dimana $\mathcal{P}_{1}$ adalah matriks orthonormal. Dengan demikian untuk merekontruksi data $\boldsymbol{X}$ dari koefisien DWT jika dekomposisi dilakukan pada level pertama yaitu:

$$
\boldsymbol{X}=\mathcal{P}_{1}^{T}\left[\begin{array}{c}
W_{1} \\
V_{1}
\end{array}\right]=\left[\begin{array}{ll}
\mathcal{W}_{1}{ }^{T} & \mathcal{V}_{1}^{T}
\end{array}\right]\left[\begin{array}{c}
W_{1} \\
V_{1}
\end{array}\right]=\mathcal{W}_{1}^{T} W_{1}+\mathcal{V}_{1}^{T} V_{1}
$$

\subsubsection{Maximal Overlap Discrete Wavelet Transform (MODWT)}

Maximal Overlap Discrete Wavelet Transform (MODWT) adalah bentuk modifikasi dari transformasi wavelet diskrit. MODWT memiliki kelebihan yaitu dapat digunakan untuk setiap ukuran sampel $N$. Maka dalam MODWT terdapat $N$ koefisien wavelet dan koefisien skala pada setiap level MODWT (Percival dan Walden, 2000). Filter wavelet dan filter skala pada MODWT dapat ditentukan berdasarkan filter wavelet dan filter skala pada DWT. Untuk menjelaskan hubungan filter wavelet dan filter skala antara DWT dengan MODWT, dapat didefinisikan filter wavelet MODWT $\left\{\tilde{h}_{l}\right\}$ terbentuk dari $\tilde{h}_{l} \equiv h_{l} / \sqrt{2}$ dan filter skala MODWT $\left\{\tilde{g}_{l}\right\}$ terbentuk dari $\tilde{g}_{l} \equiv g_{l} / \sqrt{2}$. Sehingga syarat suatu wavelet MODWT harus memenuhi persamaan (7).

$$
\sum_{l=0}^{L-1} \tilde{h}_{l}=0, \sum_{l=0}^{L-1} \tilde{h}_{l}{ }^{2}=\frac{1}{2} \text { dan } \sum_{l=0}^{L-1} \tilde{h}_{l} \tilde{h}_{l+2 m}=0
$$

dan filter skala MODWT harus memenuhi persamaan (8).

$$
\sum_{l=0}^{L-1} \tilde{g}_{l}=1, \sum_{l=0}^{L-1} \tilde{g}_{l}^{2}=\frac{1}{2} \text { dan } \sum_{l=0}^{L-1} \tilde{g}_{l} \tilde{g}_{l+2 m}
$$

dimana $m=1,2, \ldots,(L / 2)-1$. Masing-masing filter MODWT memiliki lebar $L_{j} \equiv$ $\left(2^{j}-1\right)(L-1)+1$.

Dengan mendefinisikan $\tilde{V}$ yang merupakan matriks $N \times N$ yang berisikan filter $\tilde{g}$ dan $\widetilde{W}$ yang merupakan matriks $N \times N$ yang berisikan filter $\tilde{h}$.Misalkan untuk level pertama, diketahui $L$ = 4 dan $N>4$, maka matriks $\widetilde{W}_{1}$ dan $\widetilde{V}_{1}$ dapat dilihat sebagai berikut: 


$$
\widetilde{W}_{1}=\left[\begin{array}{cccccccccccc}
\tilde{h}_{0} & 0 & 0 & \ldots & 0 & 0 & 0 & 0 & 0 & \tilde{h}_{3} & \tilde{h}_{2} & \tilde{h}_{1} \\
\tilde{h}_{1} & \tilde{h}_{0} & 0 & \ldots & 0 & 0 & 0 & 0 & 0 & 0 & \tilde{h}_{3} & \tilde{h}_{2} \\
\tilde{h}_{2} & \tilde{h}_{1} & \tilde{h}_{0} & \ldots & 0 & 0 & 0 & 0 & 0 & 0 & 0 & \tilde{h}_{3} \\
\vdots & \vdots & \vdots & \ldots & \vdots & \vdots & \vdots & \vdots & \vdots & \vdots & \vdots & \vdots \\
0 & 0 & 0 & \ldots & 0 & 0 & \tilde{h}_{3} & \tilde{h}_{2} & \tilde{h}_{1} & \tilde{h}_{0} & 0 & 0 \\
0 & 0 & 0 & \ldots & 0 & 0 & 0 & \tilde{h}_{3} & \tilde{h}_{2} & \tilde{h}_{1} & \tilde{h}_{0} & 0 \\
0 & 0 & 0 & \ldots & 0 & 0 & 0 & 0 & \tilde{h}_{3} & \tilde{h}_{2} & \tilde{h}_{1} & \tilde{h}_{0}
\end{array}\right]
$$

$\widetilde{V}_{1}$ disusun berdasarkan dimana strukturnya sama dengan $\widetilde{W}_{1}$ namun $\widetilde{h}_{l}$ diganti dengan $\tilde{g}_{l}$. Matriks filter skala dapat dilihat dengan struktur sebagai berikut:

$$
\tilde{V}_{1}=\left[\begin{array}{cccccccccccc}
\tilde{g}_{0} & 0 & 0 & \ldots & 0 & 0 & 0 & 0 & 0 & \tilde{g}_{3} & \tilde{g}_{2} & \tilde{g}_{1} \\
\tilde{g}_{1} & \tilde{g}_{0} & 0 & \ldots & 0 & 0 & 0 & 0 & 0 & 0 & \tilde{g}_{3} & \tilde{g}_{2} \\
\tilde{g}_{2} & \tilde{g}_{1} & \tilde{g}_{0} & \ldots & 0 & 0 & 0 & 0 & 0 & 0 & 0 & \tilde{g}_{3} \\
\vdots & \vdots & \vdots & \ldots & \vdots & \vdots & \vdots & \vdots & \vdots & \vdots & \vdots & \vdots \\
0 & 0 & 0 & \ldots & 0 & 0 & \tilde{g}_{3} & \tilde{g}_{2} & \tilde{g}_{1} & \tilde{g}_{0} & 0 & 0 \\
0 & 0 & 0 & \ldots & 0 & 0 & 0 & \tilde{g}_{3} & \tilde{g}_{2} & \tilde{g}_{1} & \tilde{g}_{0} & 0 \\
0 & 0 & 0 & \ldots & 0 & 0 & 0 & 0 & \tilde{g}_{3} & \tilde{g}_{2} & \tilde{g}_{1} & \tilde{g}_{0}
\end{array}\right]
$$

\subsubsection{Wavelet Haar}

Wavelet Haar merupakan wavelet paling tua dan sederhana. Haar wavelet pertama kalinya ditemukan oleh Alfred Haar pada tahun 1910 (Suparti, 2016). Wavelet Haar mempunyai rumus sebagai berikut:

dan

$$
\phi(x)= \begin{cases}1 & , \quad 0 \leq x<1 \\ 0 & , x \text { yang lain }\end{cases}
$$

$$
\psi(x)=\left\{\begin{array}{cc}
1, & 0 \leq x<1 / 2 \\
-1, & 1 / 2 \leq x<1 \\
0, & x \text { yang lain }
\end{array}\right.
$$

Wavelet Haar level $j=1$ memiliki $L_{j}=L=2$. Dengan menghitung filter wavelet dan filter skala wavelet Haar MODWT level 1 sesuai pada persamaan (7) dan (8) maka diperoleh filter wavelet yaitu $\tilde{h}_{0}=\frac{1}{2}, \tilde{h}_{1}=-\frac{1}{2}$ dan filter skala yaitu $\tilde{g}_{0}=\frac{1}{2}, \tilde{g}_{1}=-\frac{1}{2}$.

\subsection{Neural Network}

Neural network pertama kali diperkenalkan oleh McCulloch dan Pitts pada tahun 1943 yaitu berupa suatu model sederhana dari suatu syaraf nyata dalam otak manusia. Menurut Warsito (2009), prinsip dari pemodelan neural network dikembangkan dari karakteristik cara kerja otak manusia, dimana dalam memproses informasi otak manusia terdiri dari sejumlah neuron yang melakukan tugas sederhana. Karena adanya keterhubungan antar neuron, maka otak manusia dapat melakukan fungsi pemrosesan yang sangat kompleks.

Seperti halnya otak manusia, neural network juga terdiri dari beberapa neuron yang saling terhubung. Neuron-neuron tersebut akan mentransformasikan informasi yang diterima melalui sambungan keluarnya menuju ke neuron-neuron pada lapisan berikutnya. Pada neural network ini dikenal dengan nama bobot. 


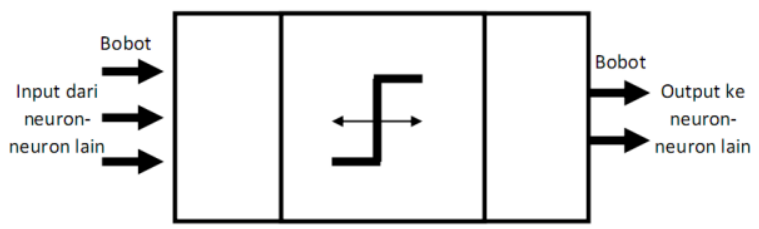

Gambar 1. Struktur neuron jaringan syaraf tiruan

Setiap neuon mempunya tingkat aktivasi yang merupakan fungsi dari input yang masuk padanya. Aktivasi yang dikirim dari suatu neuron ke neuron yang lain berupa sinyal dan hanya dapat mengirim sekali dalam satu waktu, meskipun sinyal tersebut disebarkan pada beberapa neuron lainnya. Misalkan sebuah neuron $\mathrm{Y}$ menerima input dari neuronneuron $X_{1}, X_{2}, \ldots, X_{n}$ dengan aktivasi masing-masing $x_{1}, x_{2}, \ldots, x_{n}$ dan bobot koneksi $w_{1}, w_{2}, \ldots, w_{n}$. Input jaringan pada neuron ke-j adalah:

$$
y_{i n_{j}}=\sum_{i=1}^{n} x_{i} w_{i j}
$$

dalam hal ini $w_{i j}$ adalah bobot yang menghubungkan input ke-i menuju neuron ke-j dan $y_{i n_{j}}$ menyatakan jumlah sinyal input berbobot pada lapisan tersembunyi pada neuron ke-j.

Menurut Suyanto (2008), fungsi aktivasi akan menentukan nilai output dari sebuah neuron pada suatu level aktivasi tertentu berdasarkan nilai output dari pengombinasi linier. Pemilihan fungsi aktivasi disesuaikan dengan permasalahan yang akan digunakan.

Fungsi aktivasi sigmoid biner digunakan untuk jaringan syaraf tiruan yang dilatih dengan menggunakan metode backpropagation. Fungsi sigmoid biner memiliki nilai pada range 0 sampai 1 . Secara sistematis, fungsi sigmoid biner dituliskan sebagai berikut:

$$
y=f(x)=\frac{1}{1+e^{-\sigma x}}
$$

dengan: $f^{\prime}(x)=\sigma f(x)[1-f(x)]$

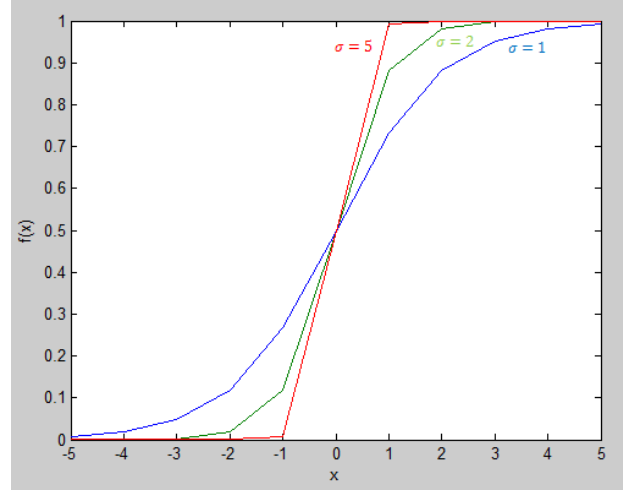

Gambar 2. Fungsi aktivasi sigmoid biner

\subsubsection{Model Feed Forward Neural Network}

Feed forward neural network (FFNN) merupakan salah satu model neural network yang dipakai dalam berbagai bidang. Arsitektur model FFNN terdiri atas satu lapis input, satu atau lebih lapis tersembunyi, dan satu lapis output. Kompleksitas dari arsitektur FFNN tergantung pada jumlah lapis tersembunyi dan jumlah neuron pada masing-masing lapis. 
Gambar 3 adalah arsitektur feed forward neural network dengan $n$ buah input (ditambah sebuah bias), sebuah hidden layer yang terdiri dari $p$ unit (ditambah sebuah bias), serta $m$ buah unit output.

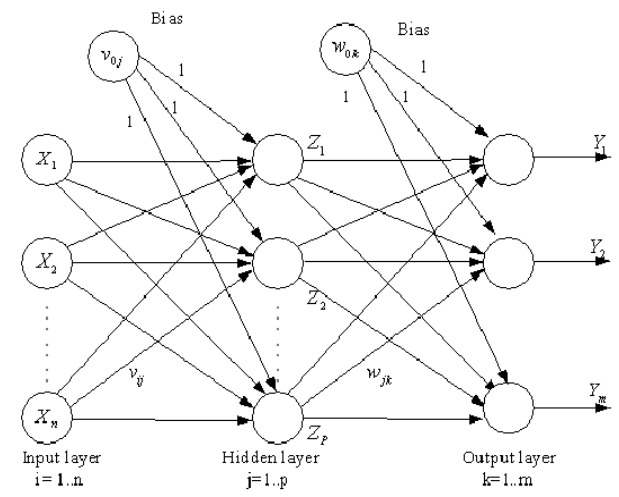

Gambar 3. Arsitektur feedforward neural network

Menurut Kusumadewi (2014), algoritma backpropagation disebut sebagai propagasi balik karena ketika jaringan diberikan pola masukan sebagai pola pelatihan maka pola tersebut menuju ke unit-unit pada lapisan tersembunyi untuk diteruskan ke unit-unit lapisan output. Selanjutnya, unit-unit lapisan output memberikan tanggapan yang disebut sebagai keluaran jaringan. Saat keluaran jaringan tidak sama dengan keluaran yang diharapkan maka keluaran akan menyebar mundur (backward) pada lapisan tersembunyi diteruskan ke unit pada lapisan input. Oleh karenanya mekanisme pelatihan tersebut dinamakan backpropagation.

\subsubsection{Model Wavelet Neural Network Untuk Time Series}

Wavelet neural network (WNN) adalah kombinasi dari analisis wavelet dan jaringan syaraf tiruan, yang memiliki frekuensi wavelet lokal frekuensi-frekuensi dan kemampuan pemetaan non linier dari jaringan syaraf tiruan. Menurut Warsito (2017), ide dasar dari model wavelet neural network adalah menggunakan koefisien-koefisien yang didapatkan dari hasil dekomposisi untuk mendapatkan ramalan nilai $X_{t}$ dengan suatu arsitektur neural network tertentu. Secara umum input untuk prediksi data time series adalah koefisien wavelet dan koefisien skala yang dihasilkan dari transformasi MODWT. Pada kenyataannya tidak semua lag dari vektor koefisien wavelet maupun koefisien skala dijadikan input. Jika pada setiap level dekomposisi $j$ lag yang dipilih menjadi input adalah 1 sampai $A_{j}$ maka estimasi untuk $X_{t}$ dapat dituliskan dengan:

$$
\hat{X}_{t}=\sum_{j=1}^{J} \sum_{k=1}^{A_{j}}\left(\hat{a}_{j, k} w_{j, t-k}+\hat{a}_{j, k} v_{j, t-k}\right)
$$

Simbol $J$ mennyatakan level dekomposisi sedangkan $A_{j}$ menjelaskan banyaknya koefisien pada setiap level. Jika banyaknya lag pada setiap level sama, yaitu $A_{j}=A$, untuk setiap level $j$, maka banyaknya variabel yang menjadi kandidat input adalah $2 A_{j}$. Lalu lag koefisien skala yang dimasukkan ke dalam model hanya pada level ke- $J\left(v_{j, t-k}\right)$ sehingga persamaan (13) menjadi: 


$$
\hat{X}_{t}=\sum_{j=1}^{J} \sum_{k=1}^{A_{j}} \hat{a}_{j, k} w_{j, t-k}+\sum_{k=1}^{A_{J+1}} \hat{a}_{J+1, k} v_{J, t-k}
$$

Tahap selanjutnya adalah pembentukan model WNN. Misalkan diberikan himpunan training dengan $t$ elemen, $X=\left(X_{0}, X_{1}, \ldots, X_{t-1}\right)$ dan diasumsikan bahwa $X_{t}$ akan diprediksi. Ide dasar dari model WNN adalah menggunakan koefisien-koefisien yang diperoleh dari dekomposisi seperti pada persamaan (42) untuk mendapatkan prediksi $X_{t}$ dengan arsitektur NN tertentu. Model WNN dengan arsitekturr FFNN untuk memproses koefisien-koefis ien wavelet yang terdiri dari satu hidden layer dengan $P$ neuron dapat dituliskan dengan:

$$
\hat{X}_{t}=\sum_{p=1}^{P} \hat{b}_{p} f^{h}\left(\sum_{j=1}^{J} \sum_{k=1}^{A_{j}} \hat{a}_{j, k, p} w_{j, t-k}+\sum_{k=1}^{A_{J+1}} \hat{a}_{J+1, k, p} v_{J, t-k}\right)
$$

dengan :

$$
\begin{array}{ll}
\hat{X}_{t+1} \cdot & \text { nilai ramalannya } \\
f^{h} & =\text { fungsi aktivasi pada lapisan tersembunyi } \\
j & =\text { level dekomposisi }(j=1,2, \ldots, J) \\
= & \text { banyaknya koefisien yang terpilih pada setiap level dekomposisi } \\
& \left(k=1,2, \ldots, A_{j}\right) \\
A_{j} & \text { nilai koefisien wavelet pada waktu } \mathrm{t}+1 \\
w_{j, t-2^{J}(k-1)} & \text { nilai koefisien skala pada waktu } \mathrm{t}+1 \\
v_{j, t-2^{J}(k-1)} & \text { nilai koefisien MAR } \\
\hat{a}_{j, k} &
\end{array}
$$

\subsection{Kriteria Pemilihan Model Peramalan Terbaik}

Kesalahan peramalan dapat dihitung dengan menggunakan selisih antara nilai asli dengan nilai peralamannya, yang umumnya disebut error atau galat. Pada penelitian ini kriteria pemilihan podel peramalan terbaik menggunakan Mean Absolute Percentage Errors (MAPE).

Nilai MAPE memberikan petunjuk seberapa besar rata-rata kesalahan absolut peramalan dibandingkan dengan nilai sebenarnya, dengan rumus:

$$
M A P E=\frac{1}{n} \sum_{t=1}^{n}\left|\frac{e_{t}}{X_{t}}\right| \times 100 \%
$$

dengan $n$ adalah jumlah data, $e_{t}$ adalah nilai dari kesalahan ramalan yang diperoleh dari $X_{t}-\hat{X}_{t}$ dimana $X_{t}$ merupakan nilai data aktual dan $\hat{X}_{t}$ merupakan nilai ramalannya.

\section{HASIL DAN PEMBAHASAN}

\subsection{Proses Wavelet}

Data nilai harian kurs jual rupiah terhadap dolar AS periode 3 Januari 2017 sampai 31 Oktober 2018 menunjukkan pola runtun waktu yang ditunjukkan pada plot time series data dengan menggunakan software Minitab 17 sebagai berikut: 


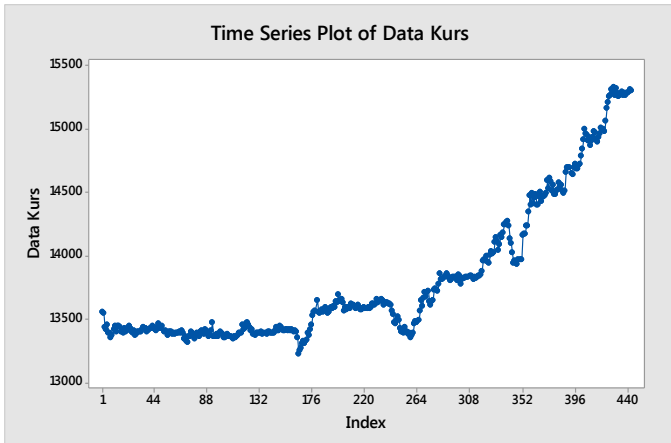

Gambar 4. Plot time series nilai kurs jual rupiah terhadap dolar AS

Berdasarkan grafik plot time series pada Gambar 4 menunjukkan ketidakstasioneran dari data. Proses selanjutnya yaitu dengan melakukan transformasi wavelet dengan mendekomposisikan data sebenarnya menjadi data koefisien skala $(v)$ dan data koefisien wavelet $(w)$ dengan menggunakan MODWT Haar level 1.

\subsection{Proses Neural Network}

Data input ditentukan dengan menggunakan plot fungsi autokorelasi parsial (PACF) dari hasi MODWT. Banyak lag yang keluar atau melebihi batas garis signifikansi menunjukkan banyaknya variabel yang akan digunakan dalam membangun model.
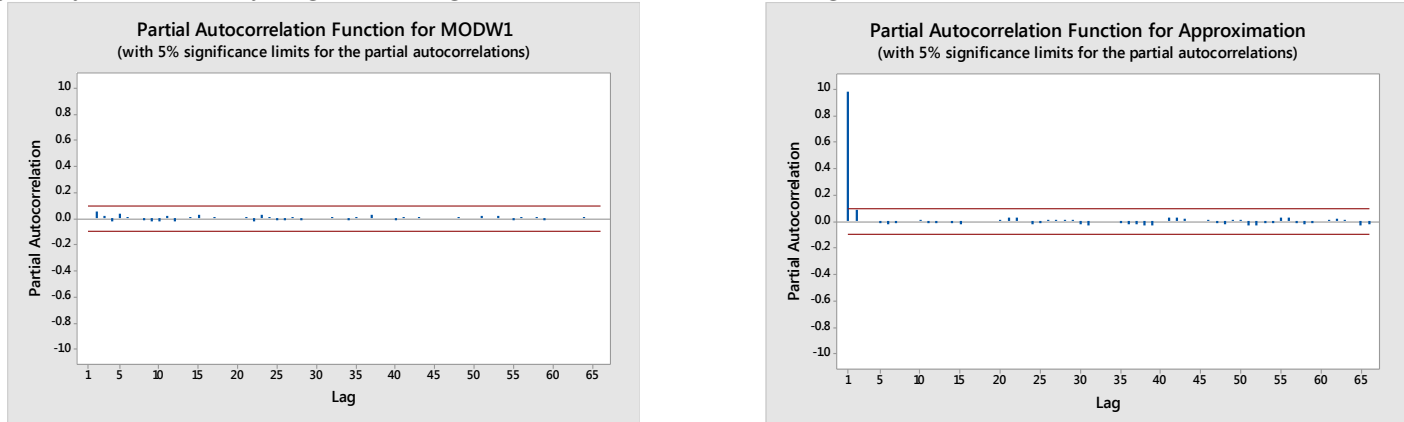

Gambar 5. Plot PACF hasil dekomposisi koefisien wavelet dan koefisien skala

Berdasarkan Gambar 5, lag yang keluar ada pada lag ke-1 dan 2 pada data hasil dekomposisi koefisien skala sehingga model yang akan dibangun menggunakan 2 variabel input. Input yang diperoleh adalah $v_{1}, v_{2}$ dengan target output $y_{i}$. Pasangaan input-output sebanyak 441 data yang telah dipilih. Setelah komponen input terpilih, data dibagi menjadi $80 \%$ untuk data pelatihan (traning) dan $20 \%$ untuk data pengujian (testing). Pembelajaran Backpropagation dilakukan dengan menentukan banyaknya neuron pada lapis tersembunyi Model yang terbaik dipilih berdasarkan nilai MAPE yang terkecil.

Tabel 1. Nilai MAPE dari Setiap Neuron Lapisan Tersembunyi.

\begin{tabular}{|c|l|l|c|l|l|}
\hline \multirow{3}{*}{$\begin{array}{l}\text { Neuron } \\
\text { Tersembunyi }\end{array}$} & Training & Testing & & Training & Testing \\
\cline { 2 - 3 } \cline { 5 - 6 } & MAPE & $\begin{array}{l}\text { MAPE } \\
(\%)\end{array}$ & $\begin{array}{l}\text { Neuron } \\
\text { Tersembunyi }\end{array}$ & $\begin{array}{l}\text { MAPE } \\
(\%)\end{array}$ & $\begin{array}{l}\text { MAPE } \\
(\%)\end{array}$ \\
\hline 1 & 0,1783 & 0,2643 & 6 & 0,1722 & 0,2259 \\
\hline 2 & 0,1747 & 0,2554 & 7 & 0,1707 & 0,2367 \\
\hline 3 & 0,1820 & 0,2633 & 8 & 0,1772 & 0,3033 \\
\hline 4 & 0,1893 & 0,2291 & 9 & 0,1807 & 0,2721 \\
\hline 5 & 0,1802 & 0,2526 & $10^{*}$ & 0,1745 & 0,2221 \\
\hline
\end{tabular}


Berdasarkan Tabel 1 diperoleh nilai MAPE testing terkecil yaitu 10 neuron lapisan hidden sebesar $0,2221 \%$. Sehingga jaringan terbaik untuk model rata-rata adalah jaringan dengan 2 neuron lapisan input, 10 neuron lapisan hidden, dan 1 neuron lapisan output.
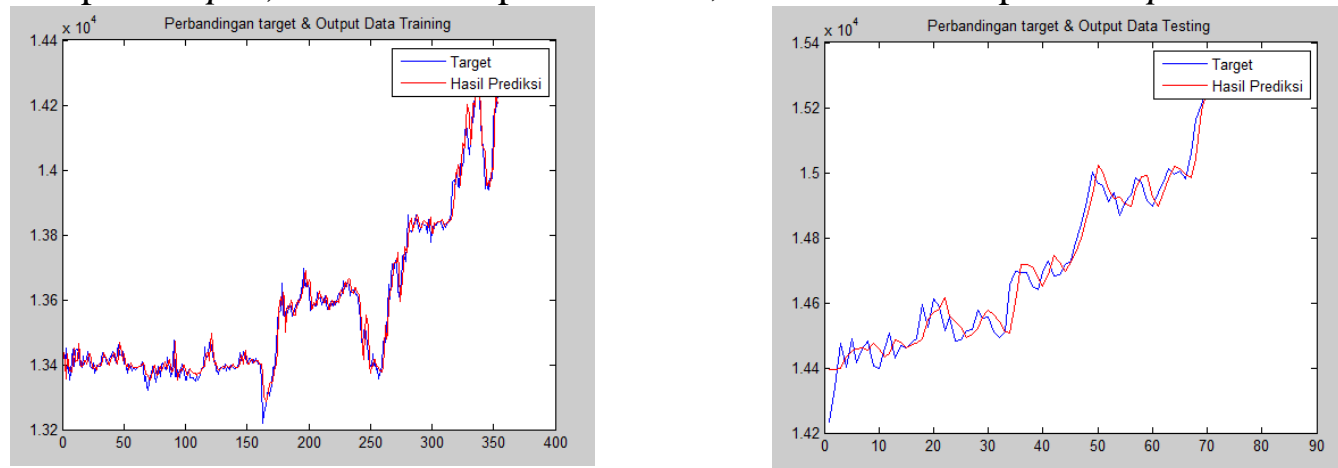

Gambar 6. Grafik perbandingan target dan output pada data training dan testing

Pada bagian ini akan diberikan hasil perbandingan ketepatan ramalan pada data testing. Evaluasi perbandingan akan dilakukan dengan model Neural Network dengan jumlah neuron input, hidden dan output yang sama.

Tabel 2. Hasil Perbandingan Ketepatan Ramalan pada Data Testing.

\begin{tabular}{|l|c|l|}
\hline Metode & Jumlah Neuron Lapisan & MAPE \\
\hline WNN & $2-10-1$ & $0,2221 \%$ \\
\hline NN & $2-10-1$ & $0,2445 \%$ \\
\hline
\end{tabular}

Nilai MAPE pada WNN yaitu sebesar $0,2221 \%$ lebih kecil dibanding dengan nilai MAPE pada NN yaitu sebesar $0,2445 \%$. Hal ini menunjukkan bahwa pemodelan Wavelet Neural Network lebih optimal digunakan untuk prediksi data time series.

\section{KESIMPULAN}

Berdasarkan hasil pembahasan pemodelan prediksi nilai tukar rupiah terhadap dolar AS menggunakan model Wavelet Neural Network, diperoleh kesimpulan bahwa dengan menggunakan model jaringan dengan 2 neuron lapisan input, 10 neuron lapisan hidden, dan 1 neuron lapisan output memberikan nilai MAPE pada data testing yang lebih kecil dibanding dengan model Neural Network yaitu $0,2221 \%<0,2445 \%$. Sehingga dapat disimpulkan untuk studi kasus nilai kurs jual rupiah terhadap dolar AS periode 3 Januari 2017 sampai 31 Oktober 2018 metode Wavelet Neural Network lebih optimal.

\section{DAFTAR PUSTAKA}

Indrabayu dkk. 2011. Prediksi Hujan di Wilayah Makassar Menggunakan Metode WaveletNeuralNetwork. Jurnal Ilmiah Elektrikal Enjiniring UNHAS, Volume 9, Nomor 2, 5058 .

Kusumadewi, F. 2014. Peramalan Harga Emas Menggunakan Feed Forward Neural Network dengan Algoritma Backpropagation. Skripsi. Universitas Negeri Yogyakarta. Percival, D.B. and Walden, A.T. 2000. Wavelet Methods for Time Series Analysis. Cambridge University Press. Cambridge, United Kingdom.

Setiaji, A. 2014. Aplikasi Model Wavelet-Neuro-Fuzzy Untuk Memprediksi NilaiTukar Euro Terhadap Dollar Amerika. Jurnal Matematika Universitas Negeri Yogyakarta, Edisi $\mathrm{V}$, Volume III. 
Septiarini, T. W., Abadi, A., \& Taufik, M. R. (2016). Application of Wavelet Fuzzy Model to Forecast the Exchange Rate IDR of USD. International Journal of Modeling and Optimization, Volume 6, Nomor 1, 66-70.

Simorangkir, I. dan Suseno. 2004. Sistem dan Kebijakan Nilai Tukar. Jakarta: Pusat Pendidikan dan Studi Kebanksentralan (PPSK) Bank Indonesia.

Subanar dan Suhartono. 2009. Wavelet Neural Networks Untuk Peramalan Data Time Series Finansial. Tesis. Universitas Gadjah Mada Yogyakarta.

Triyono. 2008. Analisis Perubahan Kurs Rupiah Terhadap Dollar Amerika. JurnalEkonomi Pembangunan, Volume 9, Nomor 2, 156-167.

Utomo, D. B. 2007. Wavelet-Jaringan Syaraf Tiruan Untuk Prediksi Data Time Series. Jurnal Math and Its Appl, Volume 4, Nomor 2, 53-64.

Wahyuningrum, S., Suparti, Mukid, M. A. 2014. Analisis Pajak Kendaraan Bermotor Menggunakan Model Multiscale Autoregressive dengan Maximal Overlap Discrete Wavelet Transform. Jurnal Gaussian, Volume 3, Nomor 1, 131-140.

Warsito, B. 2009. Kapita Selekta Statistika Neural Network. Semarang: BP UNDIP Semarang.

Warsito, B. 2006. Perbandingan Model Feed Forward Neural Network dan Generelaized Regression NeuralNetwork Pada Data Nilai Tukar Yen Terhadap Dolar AS. Prosiding SPMIPA, Hal 127-131.

Warsito, B., Subanar dan Abdurakhman. 2013. Pemodelan Time Series dengan Maximal Overlap Discrete Wavelet Transform. Prosiding Seminar Nasional Statistika. Universitas Diponegoro.

Wiliansa, G. dan Kusumawati, R. 2017. Optimasi Fuzzy Backpropagation Neural Network dengan Algoritma Genetika untuk Memprediksi Nilai Tukar Rupiah Terhadap Dollar Amerika. 10 Jurnal Matematika, Volume 6, Nomor 3. 